\title{
Therapeutic Uses of Exosomes
}

\author{
Review Article
}

\section{Zacharias E. Suntres ${ }^{1 *}$, Milton G. Smith², Fatemeh Momen-Heravi ${ }^{3,8}$, Jie Hu ${ }^{4}$, Xin Zhang ${ }^{4}$, Ying $\mathrm{Wu}^{5}$, Hongguang Zhu ${ }^{5}$, Jiping Wang ${ }^{6}$, Jian Zhou ${ }^{4}$ and Winston Patrick Kuo ${ }^{3,7}$}

\author{
1 Northern Ontario School of Medicine, Thunder Bay, Ontario, Canada \\ 2 Borgess Hospital, Kalamazoo, MI, USA \\ 3 Harvard Catalyst Laboratory for Innovative Translational Technologies, Harvard Medical School, Boston, MA, USA \\ 4 Liver Cancer Institute, Zhongshan Hospital, Fudan University, Shanghai, China \\ 5 Department of Pathology, Shanghai Medical College, Fudan University, Shanghai, China \\ 6 Division of Surgical Oncology, Brigham and Women's Hospital, Harvard Medical School, USA \\ 7 Department of Developmental Biology, Harvard School of Dental Medicine, Cambridge, MA, USA \\ 8 Department of Medicine, University of Massachusetts Medical School, Worcester, MA, USA \\ *Corresponding author(s) E-mail: zsuntres@nosm.ca
}

Received ; Accepted 26 March 2013

DOI: 0000

(C) 2013 The Author(s). Licensee InTech. This is an open access article distributed under the terms of the Creative Commons Attribution License (http://creativecommons.org/licenses/by/3.0), which permits unrestricted use, distribution, and reproduction in any medium, provided the original work is properly cited.

\begin{abstract}
Exosomes are membrane vesicles with a diameter of 40-100 $\mathrm{nm}$ that are secreted by many cell types into the extracellular milieu. Exosomes are found in cell culture supernatants and in different biological fluids and are known to be secreted by most cell types under normal and pathological conditions. Considerable research is focusing on the exploitation of exosomes in biological fluids for biomarkers in the diagnosis of disease. More recently, exosomes are being exploited for their therapeutic potential. Exosomes derived from dendritic cells, tumor cells, and malignant effusions demonstrate immunomodulatory functions and are able to present antigens to T-cells and stimulate antigenspecific T-cell responses. Exosomes have also been examined for their therapeutic potential in the treatment of infections such as toxoplasmosis, diphtheria, tuberculosis and atypical severe acute respiratory syndrome as well as autoimmune diseases. Attempts to find practical applications for exosomes continue to expand with the role of exosomes as a drug delivery system for the treatment of autoimmune/inflammatory diseases and cancers.
\end{abstract}

Keywords Exosomes, Therapy, Delivery

\section{Introduction}

Exosomes are membrane vesicles with a diameter of 40-100 $\mathrm{nm}$, a sub-fraction of extracellular vesicles that are secreted by many cell types into the extracellular milieu [1, 2]. They are equivalent to cytoplasm enclosed in a lipid bilayer with the external domains of transmembrane proteins exposed to the extracellular environment. Exosomes form in a particular population of endosomes, called multivesicular bodies (MVBs), by inward budding into the lumen of the compartment. Upon fusion of MVBs with the plasma membrane, these internal vesicles are secreted. While the biological function of exosomes is still under investigation, they can mediate communication between cells, provide a protective effect against or induce intra-and extracellular stress and are involved in the exchange of functional genetic information [1-3].

Exosomes are found in cell culture supernatants and in different biological fluids and are known to be secreted by most cell types under normal and pathological conditions. So far, exosomes have been found to be 
released by all cells examined today such as B-cells, dendritic cells (DCs), T-cells, mast cells, epithelial cells, and platelets and have been found to be present in physiological fluids, such as bronchoalveolar lavage (BAL) fluid, serum, urine, breast milk, cerebrospinal fluid, saliva, and malignant effusions [4-14]. The presence of exosomes in biological fluids could be exploited for biomarkers in the diagnosis of disease [12, 13, 15-20].

The protein composition of exosomes has been characterized using immunoblotting [21], peptide mass spectroscopy mapping [22], and affinity extraction into magnetic beads, followed by phenotyping by flow cytometry [23]. Exosomes derived from dendritic cells [22, 24], B lymphocytes [21], intestinal epithelial cells [25] and other cell types [26-33] revealed the presence of common as well as cell type specific proteins. Exosomes from different cellular origins sequester a common set of molecules that are essential for their biogenesis, structure and trafficking - as well as celltype specific components which, presumably, reflect the biological function of the parent cell. Ubiquitous proteins in exosomes include cytoplasmic proteins, such as tubulin, actin and actin-binding proteins, the heat shock proteins Hsp70 and Hsp90, and trimeric G proteins, as well as membrane proteins, such as members of the tetraspanin family (CD9, CD63, CD81, CD82) [37], which have been suggested to be involved in cell adhesion, activation, proliferation and antigen presentation. In addition to the conserved set of proteins, exosome functionality seems to be determined by cell-type specific proteins that reflect the specialized function of the original cells. For example, exosomes originated from dendritic cells are enriched with major histocompatibility complex (MHC) class I and II and express co-stimulatory molecules like CD54, CD80 and CD86 (also known as ICAM-1, B7-1 and B7-2, respectively) suggesting a T-cell stimulatory capacity [15, 22, 24, 32-34]. Exosomes from synovial fluid contain citrullinated proteins (eg. fibrin $\alpha$-chain fragment, fibrin $\beta$-chain, fibrinogen $\mathrm{D}$ fragment and $\mathrm{Sp} \alpha$ receptor) which might play an important role in converting nonimmunogenic proteins into autoimmunogenic proteins [35]. Exosomes collected in the urine contain aquaporin- 2 which might be used as a biomarker for renal diseases [36].

Lipids found on exosomes are characteristic of the cell origin, with most of the lipid analytical work being performed on exosomes derived from cancer cells, reticulocytes, mast cells, B lymphocyte cell lines and human DCs [37-40]. The typical lipid composition of mast cell-derived exosomes includes lysophosphatidylcholine, sphingomyelin, phosphatidylcholine, phosphatidylserine, phosphatidylethanolamine, cholesterol and diglyceride [40]. Although most of these lipids are also present on exosomes isolated from other cell types, the ratios of these lipids vary. For example, the ratio of cholesterol/phospholipid is lower in exosomes derived from mast cells and reticulocytes when compared with B-cell-derived exosomes [39].

\section{Isolation techniques}

Exosomes represent only a small fraction of all components present in a culture medium, cytosol or body fluids. Recognizing the fact that the exosomes have a size that range between 40 to $100 \mathrm{~nm}$, with density ranging between 1.13 and $1.21 \mathrm{~g} / \mathrm{mL}$, and contain cell type specific proteins, isolation procedures have focused on techniques based on size and density and biochemical properties. Usually, exosomes have been isolated by serial centrifugation of culture supernatant and body fluids to eliminate cells and debris which consists of multiple steps: first, a low speed spin (300 x g for 10 minutes) which eliminates dead cells and bulky apoptotic debris, followed by higher speed spins, which varies among different protocols, from $1000 \mathrm{x}$ $\mathrm{g}$ to $20,000 \mathrm{x}$ g and eliminates larger vesicles and debris. A final high speed spin at 60,000-100,000 $\mathrm{x} g$ for a period of more than 1 hour precipitates a pellet, which consists of extracellular vesicles including exosomes. Some protocols integrate the usage of filtration steps (like $0.8 \mu \mathrm{M}$ and 0.22 $\mu \mathrm{M}$ filters) and spinning to eliminate cell debris and other contaminants. However, ultracentrifugation results in the formation of a pellet that could aggregate exosomes with other vesicles, particles, apoptotic bodies or other cell debris and interfere with purification. Moreover, applying excessive centrifugation force and time may lead to rupturing the exosomes. Also, taking advantage the density properties of exosomes, they can be purified from protein aggregates, apoptotic bodies and nucleosomal fragments by floatation into a sucrose density gradient. This procedure can eliminate impurity with composition different from that of exosomes. However, with these procedures, we can only obtain exosomes heterogeneous with microvesicles, because current methods could not distinguish a 50-100nm "exosome" from a 50-200nm "microvesicle". These processes result in variable recovery of the starting amount of exosomes [13, 41-44]. Although this branch of science is growing so fast, the quality and purity of these methods for exosomes preparation do not fulfill the common good manufacturing practice (GMP) criteria. Because exosomes prepared in this way are easily contaminated with media proteins and contain only 5-25\% of starting concentration. Instead of differential centrifugation, a newer method for purifying clinical grade (cGMP) exosomes derived from antigen presenting cells employs ultrafiltration cartridges and pumps and is especially useful for purifying exosomes from large volumes ( $>1$ liter) of conditioned medium. More specifically, the ultrafiltration process were incorporated through a $500-\mathrm{kDa} \mathrm{NM}$ WCO hollow fiber cartridge that allowed the passage of unaggregated media proteins through the pores of the membrane, while retaining aggregate proteins in the retentate without significant changes on the composition and performance of the media [44]. As it is believed, the protein aggregates are much more immunogenic than the soluble form because of preferential capture by antigen presenting cells [45]. Thus, the removal of co-purifying 
proteins such as human haptoglobin and albumin aggregates prevents their undesirable immune responses to serum components [45-48]. Furthermore, during previous co-purifying with exosomes, these proteins can reach a higher concentration in the final product making it an essential aspect for the purification of cGMP exosomes.

Another isolation method, which is based on biochemical composition of exosomes utilizes magnetic beads coated with monoclonal antibody specific for a protein known to be present on the exosome membrane. For example, with the use of antibody-coated magnetic beads, using antibodies against tumor-specific proteins, it has been possible to collect HER2-expressing tumor exosomes from the culture supernatant of breast adenocarcinoma cell lines and ascites of an ovarian cancer patient $[41,43,49]$.

\section{Therapeutic use of Exosomes}

In light of the fact that exosomes secreted by neoplastic cells are close copies of the originating cells in terms of their antigenicity, the use of exosomes in cancer immunotherapy holds promise. For example, melanoma-derived exosomes contain the highly immunogenic antigens MelanA/Mart-1 and gp100 and those released by colon carcinoma cells express CEA and HER2. This antigenic content is not only a feature of in vitro-released exosomes, but also can be found in microvesicles (or fragments of plasma membrane ranging from $50 \mathrm{~nm}$ to $1000 \mathrm{~nm}$ shed from almost all cell types) isolated from plasma of cancer patients as well, evidence that demonstrates the tumor origin of these organelles $[14,50]$. Exosomes containing tumor antigens have been shown to stimulate $\mathrm{CD}^{+}$and $\mathrm{CD} 8^{+} \mathrm{T}$ cells and exosomes from in vitro cultured antigen presenting cells (APCs) administered in vivo can induce T-cell responses resulting in inhibition of tumor growth [51-53]. Also, dendritic cell-derived exosomes pulsed with tumorderived antigens elicit potent antitumor T-cell responses and tumor regression in experimental animals [14]. However, while translating findings from mouse to human, we should be cautious about the difference between human and mouse immune systems. Despite many features conserved between human and mouse systems, there are substantial differences between them. Although extensive conservation exists when comparing activated immune T-cells, the pro-inflammatory response of mice is distinct from humans. Importantly, canonical Th17 differentiation signature (IL17A, F, IL23R, RORC, BATF, and CCL20) is different in human either because of an inherently higher responsiveness of the Th17 module in human or presence of fast reactive memory $\mathrm{T}$-cells in human cells. In contrast, activation of CD24 or Lag3 seemed exclusive to mouse cells. Moreover, after pre-stimulation in similar conditions, mouse CD4 T cells activated slightly weaker than humans.

Phase I clinical trials in human cancer evaluated the effectiveness of patient-specific exosomes released by dendritic cells and loaded with tumor antigen-derived peptides (Dexosomes [Dex]) for melanoma and non-small cell lung cancer and showed that dexosome immunotherapy was feasible, safe and led to the induction of both innate and adaptive immune responses, disease stabilization and long-term survival for several patients [54, 55]. Also, ascites-derived exosomes derived from colorectal cancer patients were shown to be safe, nontoxic, and tolerable when used as a cancer vaccine, and in combination with GM-CSF can efficiently induce potent carcinoembryonic antigen (CEA)-specific antitumor immunity in advanced colorectal cancer patients [56]. It should be noted however that the potential antitumor effects of tumor-derived exosomes is still unclear as evidenced by the fact that in cancer patients with advanced disease, tumor-derived exosomes do not exert any effective immune-stimulatory or antitumor effects despite the abundant production of tumor-derived exosomes [53]. Tumor-derived exosomes have also been shown to be immunosuppressive with direct administration of tumor-derived exosomes actually resulting in promoted tumor growth [53, 54]. Tumorderived exosomes were shown to directly suppress the activity of effector T cells or target myeloid cells to modulate their differentiation and function such as in the case where exosomes derived from human melanoma cell lines and colorectal carcinoma cell lines were demonstrated to skew monocyte differentiation into DCs toward the generation of myeloid-derived suppressor cells (MDSCs) and exert TGF- $\beta 1$ mediated suppressive activity on T cells in vitro [53-55]. A better characterization of tumor-derived exosomes and understanding of their effects on cancer pathogenesis are warranted to further improve their use in cancer chemotherapy.

Exosomes are favorable as vaccine candidates in infections such as toxoplasmosis, diphtheria, tuberculosis and atypical severe acute respiratory syndrome. Toxoplasmosis is induced by the obligate intracellular parasite Toxoplamsa gondii. It has been reported that transfer of DCs pulsed with $T$. gondii antigens (TAg) to healthy mice induced protection against a virulent oral challenge of $T$. gondii but this approach is limited due to difficulty to obtain high quantity of DCs suitable for vaccination [57-59]. An alternative to DC-based vaccines being investigated is the ability of exosomes, especially those derived from DCs, to induce protective immune responses. Exosomes secreted by SRDC (CD $8 \alpha+C D 4-$ DC cell line) pulsed in vitro with Toxoplasma gondii-derived antigens (Exo-TAg) induced protective responses against infection with the parasite in both syngeneic and allogeneic mice. After oral infection, syngeneic CBA/J mice exhibited significantly fewer cysts in their brains and allogeneic C57BL/6 mice survived Immune protection is associated with the induction of humoral and cellular TAg-specific responses[60].

Exosomes have been examined for their therapeutic potential in the treatment of other infectious diseases as well. It has been shown that murine bone marrow-derived DCs (BMDCs) pulsed in vitro with intact diphtheria toxin 
(DT)-released exosomes, which upon injection into mice induce immunoglobulin $\mathrm{G}(\mathrm{IgG}) 2 \mathrm{~b}$ and IgG2a responses specific for DT [61]. Infection with M. tuberculosis primes macrophages for the increased release of exosomes and microvesicles bearing $\mathrm{M}$. tuberculosis peptide-MHC-II complexes that may generate antimicrobial T-cell responses $[62,63]$. Exosomes as a vaccine has also been explored in infection with the SARS-associated coronavirus (SARS$\mathrm{CoV}$ ) known to induce an atypical pulmonary disease with a high lethality rate. Studies by Kuate et al. demonstrated that exosomes containing spike $S$ protein of SARS-CoV induced neutralizing antibody titres and this immune response was further enhanced by priming with the SARS$S$ exosomal vaccine and then boosting with the currently used adenoviral vector vaccine [64].

Exosomes may be potential candidates as vaccines for allergic diseases. Exosome-like vesicles isolated from the bronchoalveolar lavage fluid of tolerized mice by respiratory exposure to the olive pollen allergen Ole e 1 or found to induce tolerance and protection against allergic sensitization in mice [65]. Serum containing exosomes from OVAfed experimental animals can induce tolerance to OVA when injected into naïve recipients [66, 67]. Exosomes found in breast milk [68] contain molecules such as MUC-1, MHC class I and II, CD86 and heat-shock proteins (Hsps) and have an immune regulatory role as they inhibit IL-2 and IFN- $\gamma$ production and induce Treg cells (FoxP3 ${ }^{+} \mathrm{CD} 4^{+} \mathrm{CD} 25^{+}$cells); however, the biological role of exosomes in milk and their impact on allergy development remains under investigation [15].

Exosomes have also proved useful in treatment of autoimmune diseases in animal models. Kim et al. showed that administration of exosomes derived from DCs-expressing recombinant IL-4 was able to modulate the activity of APC and T cells in vivo, partly through a FasL/Fas-dependent mechanism, resulting in effective treatment against collagen-induced arthritis through suppression of the delayed-type hypersensitivity inflammatory response [69]. Also, vaccination of mice with exosomes from IL-10, FasL, and indoleamine 2,3-dioxygenase-modified DC reduced the clinical manifestation of mice with rheumatoid arthritis [70-75]. Exosomes from TGF- $31-$ modified DCs reduced disease activity and incidence of intestinal bleeding in a murine model of inflammatory bowel disease (IBD)[75, 76].

More recently, exosomes have been seen as an alternative to liposomes in the delivery of therapeutic agents [77-79]. Exosomes are comprised of natural non-synthetic components, and their small size and flexibility enables them to cross major biological membranes, while their bi-lipid structure protects the cargo from degradation, facilitating delivery to its target $[80,81]$. In addition, these naturallyoccurring secreted membrane vesicles are less toxic, and better tolerated in the body as evidenced by their ubiquitous presence in biological fluids [80]. For example, exosomes have been used to deliver anti-inflammatory agents, such as curcumin, to activated myeloid cells in vivo. Immune dysfunction is properly investigated during various tumor growth and progression. $\mathrm{CD} 8^{+}$cytotoxic $\mathrm{T}$ lympocytes play a substantial role in antigen-specific tumor destruction and CD4+T cells assists CD8+T-cells in this scenario. Tumors frequently target and inhibit T-cell function to evade from immune response. Curcumin has been shown to inhibit the suppressive activity of T-cells via down-regulation of the production of TGF- $\beta$ and IL-10 in T-cells as well as increasing the ability of effectors T-cell to destroy cancer cells. Curcumin delivered by exosomes is more stable and more highly concentrated in the blood [82]. Exosomes can be used therapeutically to target EGFRexpressing cancerous tissues with nucleic acid drugs [83]. In this situation, targeting can be achieved by engineering the donor cells to express the transmembrane domain of platelet-derived growth factor receptor fused to the GE11 peptide. Intravenously injected exosomes delivered let-7a miRNA to EGFR-expressing xenograft breast cancer tissue in RAG2(-/-) mice [83].

Exosomes are natural carriers of RNA making them a valuable tool for the delivery of RNA interference (siRNA) and microRNA (miRNA) regulatory molecules in addition to other single-stranded oligonucleotides [84]. It has been demonstrated that exosomes can be used as vehicles for delivering siRNA to suppress the growth of cancer cells [85]. In addition, tumor-suppressive miRNAs delivered via exosomes confer a gene silencing effect on recipient cells, inhibiting cancer proliferation [86]. Dendritic cell (DC)derived exosomes have been exploited for targeted RNAi delivery to the brain after systemic injection [87]. Similarly, encapsulation of BACE (a therapeutic target in Alzheimer's disease) siRNA in exosomes derived from dendritic cells expressing Lamp2b, an exosomal membrane protein that reduces immunogenicity, fused to the neuron-specific RVG peptide resulted in delivery of BACE siRNA to the brain and decreased gene expression in neurons, microglia and oligodendrocytes in the brain [88].

Exosomes are being considered as a potential therapeutic tool in modulating neovascularization. Activation of neovascularization can lead to healing of wounds and reconstruction of hypoxic injury while hampering neovascularization delays tumor development [89]. Exosomes secreted from human CD34(+) cells have angiogenic activity in isolated endothelial cells and in murine models of vessel growth and have been postulated to represent a significant component of the paracrine effect of progenitor cell transplantation for therapeutic angiogenesis enhancing recovery from ischemic disease or injury [90]. Endothelial-derived exosomes carrying proteins such as Delta-like 4 (a transmembrane ligand for Notch receptors that is expressed in arterial blood vessels and sprouting endothelial cells) and matrix metalloproteinases lead to angiogenesis [66, 67, 89]. 
In conclusion, investigation in exosome biology has been a relatively new area of research and much work remains to be done to ensure the safe and effective use of exosomes for therapeutic applications. Exosomes appear to be noncytotoxic and well tolerated. As our understanding of the biology of exosomes intensifies, so will the range of principles for the design of exosomes and exosomal conjugates used in the development of immunotherapeutics, vaccines, and angiogenesis modulators. The role of exosomes as a next generation drug delivery system appears to be advantageous over existing drug delivery systems because of their small size, lack of toxicity and target specificity although loading of exosomes without compromising their biological properties remains a challenge.

\section{Acknowledgements}

This work was conducted with support from Harvard Catalyst I The Harvard Clinical and Translational Science Center (National Center for Research Resources and the National Center for Advancing Translational Sciences, National Institutes of Health Award 8UL1TR000170-05 and financial contributions from Harvard University and its affiliated academic health care centers). The content is solely the responsibility of the authors and does not necessarily represent the official views of Harvard Catalyst, Harvard University and its affiliated academic health care centers, or the National Institutes of Health.

\section{References}

[1] Simons M, Raposo G: Exosomes-vesicular carriers for intercellular communication. Curr Opin Cell Biol 2009, 21(4):575-581.

[2] Stoorvogel W, Kleijmeer MJ, Geuze HJ, Raposo G: The biogenesis and functions of exosomes. Traffic 2002, 3(5):321-330.

[3] Nieuwland R, Sturk A: Why do cells release vesicles? Thrombosis Research 2010, 125(Supplement 1):S49-S51.

[4] Zhou Q, Li M, Wang X, Li Q, Wang T, Zhu Q, Zhou X, Gao X, Li X: Immune-related microRNAs are abundant in breast milk exosomes. Int J Biol Sci2012, 8(1):118-123.

[5] Torregrosa Paredes P, Esser J, Admyre C, Nord M, Rahman QK, Lukic A, Radmark O, Gronneberg R, Grunewald J, Eklund A et al: Bronchoalveolar lavage fluid exosomes contribute to cytokine and leukotriene production in allergic asthma. Allergy 2012, 67(7):911-919.

[6] Street JM, Barran PE, Mackay CL, Weidt S, Balmforth C, Walsh TS, Chalmers RT, Webb DJ, Dear JW: Identification and proteomic profiling of exosomes in human cerebrospinal fluid. J Transl Med 2012, 10:5.

[7] Reinhardt TA, Lippolis JD, Nonnecke BJ, Sacco RE: Bovine milk exosome proteome. J Proteomics 2012, 75(5):1486-1492.

[8] Qazi KR, Torregrosa Paredes P, Dahlberg B, Grunewald J, Eklund A, Gabrielsson S: Proinflammatory exosomes in bronchoalveolar lavage fluid of patients with sarcoidosis. Thorax 2010, 65(11): 1016-1024.

[9] Lasser C, Alikhani VS, Ekstrom K, Eldh M, Paredes PT, Bossios A, Sjostrand M, Gabrielsson S, Lotvall J, Valadi H: Human saliva, plasma and breast milk exosomes contain RNA: uptake by macrophages. $J$ Transl Med 2011, 9:9.

[10] Keller S, Ridinger J, Rupp AK, Janssen JW, Altevogt P: Body fluid derived exosomes as a novel template for clinical diagnostics. J Transl Med 2011, 9:86.

[11] Gallo A, Tandon M, Alevizos I, Illei GG: The majority of microRNAs detectable in serum and saliva is concentrated in exosomes. PLoS One 2012, 7(3):e30679.

[12] Dimov I, Jankovic Velickovic L, Stefanovic V: Urinary exosomes. ScientificWorldJournal 2009, 9:1107-1118.

[13] Bard MP, Hegmans JP, Hemmes A, Luider TM, Willemsen R, Severijnen LA, van Meerbeeck JP, Burgers SA, Hoogsteden HC, Lambrecht BN: Proteomic analysis of exosomes isolated from human malignant pleural effusions. Am J Respir Cell Mol Biol 2004, 31(1):114-121.

[14] Andre F, Schartz NE, Movassagh M, Flament C, Pautier P, Morice P, Pomel C, Lhomme C, Escudier $\mathrm{B}$, Le Chevalier $\mathrm{T}$ et al: Malignant effusions and immunogenic tumour-derived exosomes. Lancet 2002, 360(9329):295-305.

[15] Admyre C, Telemo E, Almqvist N, Lotvall J, Lahesmaa R, Scheynius A, Gabrielsson S: Exosomes-nanovesicles with possible roles in allergic inflammation. Allergy 2008, 63(4):404-408.

[16] Little KM, Smalley DM, Harthun NL, Ley K: The plasma microparticle proteome. Semin Thromb Hemost 2010, 36(8):845-856.

[17] Nieuwland R, Sturk A: Why do cells release vesicles? Thromb Res 2010, 125 Suppl 1:S49-51.

[18] Raposo G, Nijman HW, Stoorvogel W, Liejendekker R, Harding CV, Melief CJ, Geuze HJ: B lymphocytes secrete antigen-presenting vesicles. J Exp Med 1996, 183(3):1161-1172. 
[19] Simpson RJ, Lim JW, Moritz RL, Mathivanan S: Exosomes: proteomic insights and diagnostic potential. Expert Rev Proteomics 2009, 6(3):267-283.

[20] Vidal M: Exosomes in erythropoiesis. Transfus Clin Biol 2010, 17(3):131-137.

[21] Escola JM, Kleijmeer MJ, Stoorvogel W, Griffith JM, Yoshie O, Geuze HJ: Selective enrichment of tetraspan proteins on the internal vesicles of multivesicular endosomes and on exosomes secreted by human B-lymphocytes. J Biol Chem 1998, 273(32):20121-20127.

[22] Thery C, Regnault A, Garin J, Wolfers J, Zitvogel L, Ricciardi-Castagnoli P, Raposo G, Amigorena S: Molecular characterization of dendritic cell-derived exosomes. Selective accumulation of the heat shock protein hsc73. J Cell Biol 1999, 147(3):599-610.

[23] Clayton A, Court J, Navabi H, Adams M, Mason MD, Hobot JA, Newman GR, Jasani B: Analysis of antigen presenting cell derived exosomes, based on immuno-magnetic isolation and flow cytometry. J Immunol Methods 2001, 247(1-2):163-174.

[24] Thery C, Boussac M, Veron P, Ricciardi-Castagnoli P, Raposo G, Garin J, Amigorena S: Proteomic analysis of dendritic cell-derived exosomes: a secreted subcellular compartment distinct from apoptotic vesicles. I Immunol 2001, 166(12): 7309-7318.

[25] Van Niel G, Mallegol J, Bevilacqua C, Candalh C, Brugiere S, Tomaskovic-Crook E, Heath JK, CerfBensussan N, Heyman M: Intestinal epithelial exosomes carry MHC class II/peptides able to inform the immune system in mice. Gut 2003, 52(12): 1690-1697.

[26] Chavez-Munoz C, Kilani RT, Ghahary A: Profile of exosomes related proteins released by differentiated and undifferentiated human keratinocytes. J Cell Physiol 2009, 221(1):221-231.

[27] Conde-Vancells J, Rodriguez-Suarez E, Embade N, Gil D, Matthiesen R, Valle M, Elortza F, Lu SC, Mato JM, Falcon-Perez JM: Characterization and comprehensive proteome profiling of exosomes secreted by hepatocytes. J Proteome Res 2008, 7(12):5157-5166.

[28] Giri PK, Kruh NA, Dobos KM, Schorey JS: Proteomic analysis identifies highly antigenic proteins in exosomes from $M$. tuberculosis-infected and culture filtrate protein-treated macrophages. Proteomics 2010, 10(17):3190-3202.

[29] Gonzalez-Begne M, Lu B, Han X, Hagen FK, Hand AR, Melvin JE, Yates JR: Proteomic analysis of human parotid gland exosomes by multidimensional protein identification technology (MudPIT). J Proteome Res 2009, 8(3):1304-1314.
[30] Mathivanan S, Lim JW, Tauro BJ, Ji H, Moritz RL, Simpson RJ: Proteomics analysis of A33 immunoaffinity-purified exosomes released from the human colon tumor cell line LIM1215 reveals a tissuespecific protein signature. Mol Cell Proteomics 2010, 9(2):197-208.

[31] Mathivanan S, Simpson RJ: ExoCarta: A compendium of exosomal proteins and RNA. Proteomics 2009, 9(21):4997-5000.

[32] Olver C, Vidal M: Proteomic analysis of secreted exosomes. Subcell Biochem 2007, 43:99-131.

[33] Simpson RJ, Jensen SS, Lim JW: Proteomic profiling of exosomes: current perspectives. Proteomics 2008, 8(19):4083-4099.

[34] Bourrie BJ, Casellas P, Blythman HE, Jansen FK: Study of the plasma clearance of antibody--ricin-Achain immunotoxins. Evidence for specific recognition sites on the $\mathrm{A}$ chain that mediate rapid clearance of the immunotoxin. Eur J Biochem 1986, 155(1):1-10.

[35] Skriner K, Adolph K, Jungblut PR, Burmester GR: Association of citrullinated proteins with synovial exosomes. Arthritis Rheum 2006, 54(12):3809-3814.

[36] Hoorn EJ, Pisitkun T, Zietse R, Gross P, Frokiaer J, Wang NS, Gonzales PA, Star RA, Knepper MA: Prospects for urinary proteomics: exosomes as a source of urinary biomarkers. Nephrology (Carlton) 2005, 10(3):283-290.

[37] Wubbolts R, Leckie RS, Veenhuizen PT, Schwarzmann G, Mobius W, Hoernschemeyer J, Slot JW, Geuze HJ, Stoorvogel W: Proteomic and biochemical analyses of human B cell-derived exosomes. Potential implications for their function and multivesicular body formation. J Biol Chem 2003, 278(13):10963-10972.

[38] Vidal M, Sainte-Marie J, Philippot JR, Bienvenue A: Asymmetric distribution of phospholipids in the membrane of vesicles released during in vitro maturation of guinea pig reticulocytes: evidence precluding a role for "aminophospholipid translocase". J Cell Physiol 1989, 140(3):455-462.

[39] Subra C, Laulagnier K, Perret B, Record M: Exosome lipidomics unravels lipid sorting at the level of multivesicular bodies. Biochimie 2007, 89(2):205-212.

[40] Laulagnier K, Motta C, Hamdi S, Roy S, Fauvelle F, Pageaux JF, Kobayashi T, Salles JP, Perret B, Bonnerot $\mathrm{C}$ et al: Mast cell-and dendritic cellderived exosomes display a specific lipid composition and an unusual membrane organization. Biochem J 2004, 380(Pt 1):161-171. 
[41] Le Pecq JB: Dexosomes as a therapeutic cancer vaccine: from bench to bedside. Blood Cells Mol Dis 2005, 35(2):129-135.

[42] Gonzales PA, Zhou H, Pisitkun T, Wang NS, Star RA, Knepper MA, Yuen PS: Isolation and purification of exosomes in urine. Methods Mol Biol 2010, 641:89-99.

[43] Caby MP, Lankar D, Vincendeau-Scherrer C, Raposo G, Bonnerot C: Exosomal-like vesicles are present in human blood plasma. Int Immunol 2005, 17(7):879-887.

[44] Lamparski HG, Metha-Damani A, Yao J-Y, Patel S, Hsu D-H, Ruegg C, Le Pecq J-B: Production and characterization of clinical grade exosomes derived from dendritic cells. Journal of Immunological Methods 2002, 270(2):211-226.

[45] Kovacsovics-Bankowski M, Clark K, Benacerraf B, Rock KL: Efficient major histocompatibility complex class I presentation of exogenous antigen upon phagocytosis by macrophages. Proc Natl Acad Sci U S A 1993, 90(11):4942-4946.

[46] Oh SK, Kim SH, Walker JE: Interference with immune response at the level of generating effector cells by tumor-associated haptoglobin. J Natl Cancer Inst 1990, 82(11):934-940.

[47] Jensen LB, Dam J, Teisner B: Identification and removal of polymer-and aggregate-forming proteins in human plasma albumin preparations. Vox Sang 1994, 67(2):125-131.

[48] Dobryszycka W: Biological functions of haptoglobin--new pieces to an old puzzle. Eur J Clin Chem Clin Biochem 1997, 35(9):647-654.

[49] Koga K, Matsumoto K, Akiyoshi T, Kubo M, Yamanaka N, Tasaki A, Nakashima H, Nakamura M, Kuroki S, Tanaka M et al: Purification, characterization and biological significance of tumorderived exosomes. Anticancer Res 2005, 25(6A): 3703-3707.

[50] Andreola G, Rivoltini L, Castelli C, Huber V, Perego P, Deho P, Squarcina P, Accornero P, Lozupone F, Lugini L et al: Induction of lymphocyte apoptosis by tumor cell secretion of FasL-bearing microvesicles. J Exp Med 2002, 195(10):1303-1316.

[51] Amigorena S: Anti-tumour immunotherapy using dendritic-cell-derived exosomes. Res Immunol 1998, 149(7-8):661-662.

[52] Hsu DH, Paz P, Villaflor G, Rivas A, Mehta-Damani A, Angevin E, Zitvogel L, Le Pecq JB: Exosomes as a tumor vaccine: enhancing potency through direct loading of antigenic peptides. J Immunother 2003, 26(5):440-450.
[53] Zitvogel L, Regnault A, Lozier A, Wolfers J, Flament C, Tenza D, Ricciardi-Castagnoli P, Raposo G, Amigorena S: Eradication of established murine tumors using a novel cell-free vaccine: dendritic cell-derived exosomes. Nat Med 1998, 4(5):594-600.

[54] Delcayre A, Le Pecq JB: Exosomes as novel therapeutic nanodevices. Curr Opin Mol Ther 2006, 8(1): 31-38.

[55] Viaud S, Thery C, Ploix S, Tursz T, Lapierre V, Lantz O, Zitvogel L, Chaput N: Dendritic cell-derived exosomes for cancer immunotherapy: what's next? Cancer Res 2010, 70(4):1281-1285.

[56] Dai S, Wei D, Wu Z, Zhou X, Wei X, Huang H, Li G: Phase I clinical trial of autologous ascites-derived exosomes combined with GM-CSF for colorectal cancer. Mol Ther 2008, 16(4):782-790.

[57] Aline F, Bout D, Amigorena S, Roingeard P, DimierPoisson I: Toxoplasma gondii antigen-pulseddendritic cell-derived exosomes induce a protective immune response against $\mathrm{T}$. gondii infection. Infect Immun 2004, 72(7):4127-4137.

[58] Beauvillain C, Juste MO, Dion S, Pierre J, DimierPoisson I: Exosomes are an effective vaccine against congenital toxoplasmosis in mice. Vaccine 2009, 27(11):1750-1757.

[59] Beauvillain C, Ruiz S, Guiton R, Bout D, DimierPoisson I: A vaccine based on exosomes secreted by a dendritic cell line confers protection against $\mathrm{T}$. gondii infection in syngeneic and allogeneic mice. Microbes Infect 2007, 9(14-15):1614-1622.

[60] Beauvillain C, Ruiz S, Guiton R, Bout D, DimierPoisson I: A vaccine based on exosomes secreted by a dendritic cell line confers protection against $\mathrm{T}$. gondii infection in syngeneic and allogeneic mice. Microbes and Infection, 9(14-15):1614-1622.

[61] Colino J, Snapper CM: Exosomes from bone marrow dendritic cells pulsed with diphtheria toxoid preferentially induce type 1 antigen-specific IgG responses in naive recipients in the absence of free antigen. J Immunol 2006, 177(6):3757-3762.

[62] Ramachandra L, Qu Y, Wang Y, Lewis CJ, Cobb BA, Takatsu K, Boom WH, Dubyak GR, Harding CV: Mycobacterium tuberculosis Synergizes with ATP To Induce Release of Microvesicles and Exosomes Containing Major Histocompatibility Complex Class II Molecules Capable of Antigen Presentation. Infect Immun 2010, 78(12):5116-5125.

[63] Singh PP, LeMaire C, Tan JC, Zeng E, Schorey JS: Exosomes released from $\mathrm{M}$. tuberculosis infected cells can suppress IFN-gamma mediated activation of naive macrophages. PLoS One 2011, 6(4):e18564. 
[64] Kuate S, Cinatl J, Doerr HW, Überla K: Exosomal vaccines containing the $S$ protein of the SARS coronavirus induce high levels of neutralizing antibodies. Virology 2007, 362(1):26-37.

[65] Prado N, Marazuela EG, Segura E, FernandezGarcia H, Villalba M, Thery C, Rodriguez R, Batanero E: Exosomes from bronchoalveolar fluid of tolerized mice prevent allergic reaction. J Immunol 2008, 181(2):1519-1525.

[66] Karlsson MR, Kahu H, Hanson LA, Telemo E, Dahlgren UI: An established immune response against ovalbumin is suppressed by a transferable serum factor produced after ovalbumin feeding: a role of CD25+regulatory cells. Scand J Immunol 2002, 55(5):470-477.

[67] Karlsson MR, Kahu H, Hanson LA, Telemo E, Dahlgren UI: Tolerance and bystander suppression, with involvement of CD25-positive cells, is induced in rats receiving serum from ovalbumin-fed donors. Immunology 2000, 100(3):326-333.

[68] Admyre C, Johansson SM, Qazi KR, Filen JJ, Lahesmaa R, Norman M, Neve EP, Scheynius A, Gabrielsson S: Exosomes with immune modulatory features are present in human breast milk. J Immunol 2007, 179(3):1969-1978.

[69] Kim SH, Bianco NR, Shufesky WJ, Morelli AE, Robbins PD: Effective treatment of inflammatory disease models with exosomes derived from dendritic cells genetically modified to express IL-4. J Immunol 2007, 179(4):2242-2249.

[70] Kim SH, Kim S, Oligino TJ, Robbins PD: Effective treatment of established mouse collagen-induced arthritis by systemic administration of dendritic cells genetically modified to express FasL. Mol Ther 2002, 6(5):584-590.

[71] Kim SH, Lechman ER, Bianco N, Menon R, Keravala A, Nash J, Mi Z, Watkins SC, Gambotto A, Robbins PD: Exosomes derived from IL-10-treated dendritic cells can suppress inflammation and collageninduced arthritis. J Immunol 2005, 174(10):6440-6448.

[72] Kim SH, Bianco N, Menon R, Lechman ER, Shufesky WJ, Morelli AE, Robbins PD: Exosomes derived from genetically modified DC expressing FasL are anti-inflammatory and immunosuppressive. Mol Ther 2006, 13(2):289-300.

[73] Szanto S, Koreny T, Mikecz K, Glant TT, Szekanecz Z, Varga J: Inhibition of indoleamine 2,3-dioxygenase-mediated tryptophan catabolism accelerates collagen-induced arthritis in mice. Arthritis Res Ther 2007, 9(3):R50.

[74] Yang X, Meng S, Jiang H, Chen T, Wu W: Exosomes derived from interleukin-10-treated dendritic cells can inhibit trinitrobenzene sulfonic acid-induced rat colitis. Scand J Gastroenterol 2010, 45(10): 1168-1177.

[75] Yin W, Ouyang S, Li Y, Xiao B, Yang H: Immature Dendritic Cell-Derived Exosomes: a Promise Subcellular Vaccine for Autoimmunity. Inflammation 2012.

[76] Cai Z, Zhang W, Yang F, Yu L, Yu Z, Pan J, Wang L, Cao X, Wang J: Immunosuppressive exosomes from TGF-beta1 gene-modified dendritic cells attenuate Th17-mediated inflammatory autoimmune disease by inducing regulatory T cells. Cell Res 2012, 22(3): 607-610

[77] Lai RC, Yeo RWY, Tan KH, Lim SK: Exosomes for drug delivery - a novel application for the mesenchymal stem cell. Biotechnology Advances (0).

[78] El Andaloussi S, Lakhal S, Mäger I, Wood MJA: Exosomes for targeted siRNA delivery across biological barriers. Advanced Drug Delivery Reviews (0).

[79] Suntres ZE: Liposomal Antioxidants for Protection against Oxidant-Induced Damage. J Toxicol 2011, 2011:152474.

[80] Lai RC, Yeo RW, Tan KH, Lim SK: Exosomes for drug delivery - a novel application for the mesenchymal stem cell. Biotechnol Adv 2012.

[81] Vickers KC, Remaley AT: Lipid-based carriers of microRNAs and intercellular communication. Curr Opin Lipidol 2012, 23(2):91-97.

[82] Sun D, Zhuang X, Xiang X, Liu Y, Zhang S, Liu C, Barnes S, Grizzle W, Miller D, Zhang H-G: A Novel Nanoparticle Drug Delivery System: The Antiinflammatory Activity of Curcumin Is Enhanced When Encapsulated in Exosomes. Mol Ther 2010, 18(9):1606-1614.

[83] Ohno SI, Takanashi M, Sudo K, Ueda S, Ishikawa A, Matsuyama N, Fujita K, Mizutani T, Ohgi T, Ochiya $\mathrm{T}$ et al: Systemically Injected Exosomes Targeted to EGFR Deliver Antitumor MicroRNA to Breast Cancer Cells. Mol Ther 2012.

[84] O'Loughlin AJ, Woffindale CA, Wood MJ: Exosomes and the emerging field of exosome-based gene therapy. Curr Gene Ther 2012, 12(4):262-274.

[85] Akao Y, Iio A, Itoh T, Noguchi S, Itoh Y, Ohtsuki Y, Naoe T: Microvesicle-mediated RNA molecule delivery system using monocytes/macrophages. Mol Ther 2011, 19(2):395-399.

[86] Kosaka N, Iguchi H, Yoshioka Y, Takeshita F, Matsuki Y, Ochiya T: Secretory mechanisms and intercellular transfer of microRNAs in living cells. J Biol Chem 2010, 285(23):17442-17452. 
[87] Lakhal S, Wood MJ: Exosome nanotechnology: an emerging paradigm shift in drug delivery: exploitation of exosome nanovesicles for systemic in vivo delivery of RNAi heralds new horizons for drug delivery across biological barriers. Bioessays 2011, 33(10):737-741.

[88] Alvarez-Erviti L, Seow Y, Yin H, Betts C, Lakhal S, Wood MJ: Delivery of siRNA to the mouse brain by systemic injection of targeted exosomes. Nat Biotechnol 2011, 29(4):341-345.
[89] Martinez MC, Andriantsitohaina R: Microparticles in angiogenesis: therapeutic potential. Circ Res 2011, 109(1):110-119.

[90] Sahoo S, Klychko E, Thorne T, Misener S, Schultz KM, Millay M, Ito A, Liu T, Kamide C, Agrawal H et al: Exosomes from human CD34(+) stem cells mediate their proangiogenic paracrine activity. Circ Res 2011, 109(7):724-728. 